\title{
Carpe Diem Revisited in Poetry, Fiction and Film
}

\author{
Yi Wang \\ School of Foreign Languages, Chongqing University of Posts and Telecommunications, Nan'an, Chongqing, China
}

\begin{abstract}
Carpe Diem is considered to be an eternal theme in English literature. Being pervasively spread through all ages, it is indeed of universal significance, reflecting one of the important philosophical issues of human world. Albeit this phrase was first created by Horace in ancient Rome, it has greatly influenced the renaissance poetry and the metaphysical poetry of the $17^{\text {th }}$ century. This paper sets out to analyze different representations of Carpe Diem or its variations in various literary forms, namely, poetry, fiction and even film. After these contemplations it is safe to say that the connotation of this theme is the concrete reflection of positive philosophy of life, rather than the seemingly negative ways of living life in common sense. Carpe Diem plays its due significance in the conflicts between human studies and theology, secularism and afterlife, feudalism and humanism in the history of human thoughts.
\end{abstract}

Index Terms-Carpe Diem, poetry, fiction, film

\section{INTRODUCTION}

Catch, then, oh catch the transient hour;

Improve each moment as it flies!

Life's a short summer, man a flower;

He dies - alas! How soon he dies!

-Samuel Johnson (1709-1784). Winter. An Ode.

The Carpe Diem motif is considered to be an eternal issue in English literature. As Eliot (1960: 253) put it, the Carpe Diem theme is one of the greatest traditions in European literature. Other scholars even believe that being pervasively spread through all ages, this theme is indeed of universal significance, reflecting one of the important philosophical issues of human world. In the progress of its development and variation, Carpe Diem maintains a close link to the ideas and trends of thoughts of different historical periods of Europe and of the world, and has a great significance in the history of world culture. Albeit this phrase was first created by Horace in ancient Rome, it has greatly influenced the renaissance poetry and the metaphysical poetry of the $17^{\text {th }}$ century.

This paper sets out to analyze different representations of Carpe Diem or its variations in various literary forms, namely, poetry, fiction and even film. After these contemplations it is safe to say that the connotation of this theme is the concrete reflection of positive philosophy of life, rather than the seemingly negative ways of living life in common sense. It has gone so far as to transcend the scope of literature. Carpe Diem plays its due significance in the conflicts between human studies and theology, secularism and afterlife, feudalism and humanism in the history of human thoughts.

\section{THE ORIGIN OF CARPE DIEM}

The term Carpe Diem originates from Latin language, which is usually interpreted literally as seize the day in English, in other words make the best of the present moment. In Chinese, there are quite a few versions, “把握今天”, “珍惜时 光”, “只争朝夕”, “及时行乐”, and so forth, among which “及时行乐” is regarded to be much more common and philosophical. As a matter of fact, this version quite coincides with the original meaning of Carpe Diem, just as Oxford Concise Dictionary of Literary Terms (Baldick, 2000: 31) explains:

"Carpe Diem: A common theme or motif in European lyric poetry, in which the speaker of a poem argues

(often to a hesitant virgin) that since life is short, pleasure should be enjoyed while there is still time."

From the above definition, it is crystal-clear that Carpe Diem emphasizes that life is short, time is fleeting, and that one should make the most of present pleasures.

The term Carpe Diem first appeared in the poem of Horace, an ancient Roman poet. The exact meaning of Carpe Diem can be gained from the context of Odes I. xi, in which Horace wrote as follows,

"sapias, vina liques, et spatio breui spem longam reseces. dum loquimur, fugerit inuida aetas: Carpe Diem, quam minimum credula postero."1

The following translation by Thomas Hawkins was published in The Poems of Horace ... Rendered in English Verse by Several Persons:

"Be wise, drink free, and in so short a space,

Do not protracted hopes of life embrace.

\footnotetext{
${ }^{1}$ http://www.merriampark.com/horcarm111.htm
} 
Whilest we are talking, envious Time doth slide;

This day's thine own, the next may be deny'd.",2

The synopsis of aforementioned lines is that one is supposed to give up trying to learn the secrets of the future. Be wise, do thy daily task, and live to-day; time is swiftly flying. Although it is Horace (65 - 8 B.C.) who first applied this term in his works, he is not the first poet that manifests this Carpe Diem thought in literature. There are Carpe Diem loaded works much earlier than Horace's Odes. But there is no reliable evidence available to substantiate the exact time during which this thought took place. However, it is certain that the thought of Carpe Diem has emerged in the Greek literature, the precursor of ancient roman literature.

\section{CARPE DIEM THEME IN POETRY}

In this section, Carpe Diem in poetry is analyzed in detail. Poems of $17^{\text {th }}$ century are the focus, for Carpe Diem has most deeply influenced the renaissance poems and metaphysical poems of $17^{\text {th }}$ century. The most celebrated examples are Robert Herrick's To the Virgins, To Make Much of Time (1648) and Andrew Marvell's To His Coy Mistress (1681).

In his poem, Herrick wrote,

"Gather ye rosebuds while ye may,

Old time is still a-flying;

And this same flower that smiles today,

Tomorrow will be dying.

The glorious lamp of heaven, the sun,

The higher he's a-getting,

The sooner will his race be run,

And nearer he's to setting.

That age is best which is the first,

When youth and blood are warmer,

But being spent, the worse, and the worst

Time still succeed the former.

Then be not coy, but use your time,

And while ye may, go marry:

For having lost but once your prime,

You may forever tarry." (Robert Herrick1591-1674) ${ }^{3}$

Compactly structured, the above a few poetic lines enable readers clearly comprehend the theme. In the first stanza, the writer uses the image of rose to express the transience of human life and the fleeting of time. In western culture, rose symbolizes transitory beauty. The second stanza compares the glorious lamp of heave - the one day journey of the sun, to the journey of human life. Its archetype is Apollo who, driving in his four-wheeled chariot, rises in the dawn and sets in the evening. After two analogies the speaker rushes to his motif. Triggered by the rose and the sun, readers will associate with human life. Youth is transient; envious time does slide. Therefore, the speaker admonishes that virgins be not coy, but use their time and go marry, otherwise, they may forever tarry.

To His Coy Mistress (composed in circa 1646 and published in 1681) is a lyric poem widely anthologized in college English textbooks. One of the most celebrated Carpe Diem poems in British literature, it has been praised by numerous literary scholars and critics for its brilliantly wrought form, thematic significance, metaphysical conceits, paradox, and irony. In his English Literature in the Early Seventeenth Century 1600-1660 (1962), for example, Douglas Bush notes that throughout the poem's syllogistic argument "emotional intensity and ironic wit are under such control that the lyric possesses a cavalier elegance and poise, beyond the cavalier level" (p. 173). According to George Saintsbury, author of A Short History of English Literature (1966), "[The] passionate magnificence of the Amorists...has no nobler examples than 'To His Coy Mistress,' and still more 'The Definition of Love"' (p. 426). In The Concise Cambridge History of English Literature (1970), George Sampson comments that few English poets surpass Marvell in lyric poetry. Marvell's lyrics "combine English charm and Latin gravity"; indeed, such poems as The Nymph, To His Coy Mistress, The Picture of T. C., The Garden, as well as the "Mower" pieces and the pastoral dialogues, are "worthy of a place in any anthology of the best" (p. 314). Meanwhile, Peter Quennell, in his A History of English Literature (1973), observes that To His Coy Mistress is "Marvell's most sustained effort...in which he tempers 'Metaphysical' conceits with a more forceful and spontaneous eloquence" (p. 138). ${ }^{4}$

We can follow the Carpe Diem theme beginning with the title, which immediately sets up the situation. The opening line of the poem - "Had we but world enough and time" - introduces us to the space-time continuum. Rich in possibilities of verbal patterns, the motif is much more, for the structure of the poem depends on the subjunctive concept, the condition contrary to fact, which gives the whole poem its meaning: "Had we," the speaker says, knowing that they do not. Then the speaker employs hyperbole to imagine from space-time continuum. In the first stanza, the

\footnotetext{
2 Ibid.

3 College English (Magazine). 2002.9. p. 52

${ }^{4}$ See also http://mobap.edu/academics/fl/journal/2.1/han.asp
} 
speaker offers a major premise that if we were to live this world forever and never grow old, you could be coy. And I will wait with patience.

In the second stanza, readers are surprised with the speaker's sudden change of tone, along which the theme of Tempus fugit (Time flies!) is proposed. There is a minor premise in this stanza that time is ephemeral; life is short; and death is unavoidable; my love shall wither as my life ends.

In the third stanza, the speaker of the poem sets out to persuade that "let us sport us while we may", instead of being devoured by time's scythe. The stanza is the conclusion of syllogism which states that, while we are young, let us seek physical pleasure, make love, and enjoy life.

In Edmund Spenser's The Faerie Queene (II, xii, 75), such motif also finds expression in this masterpiece.

So passeth, in the passing of a day,

Of mprtall life the leafe, the bud, the flower,

Ne more doth flourish after first decay,

That earst was sought to decke both bed and bowre,

Of many a Ladie, and many a Paramowre:

Gather therefore the Rose, whilest yet is prime,

For soone comes age, that will her pride deflower;

Gather the Rose of loue, whilest yet is time,

While louing thou mayst loued be with equall crime. (Hamilton, 1980: 295)

To the speaker of the poem, the lady is identified with the rose. The rose is something swiftly fleeting away never to return, so is the short-lived beauty of the lady.

This motif has also influenced such writers as Ben Jonson, a classicist, in the song in Act III, Scene vii of his Volpone, or the fox:

Come, my Celia, let us prove,

While we can, the sports of love,

Time will not be ours for ever,

He, at length, our good will sever. (Abrams, 1979: 1166-1167)

And Shakespeare's Twelfth Night (II, iii) reiterated this motif. The clown Feste sings the praises of seizing the day:

What is love? 'tis not hereafter;

Present mirth hath present laughter;

What's to come is still unsure.

In delay there lies no plenty,

Then come kiss me, sweet and twenty;

Youth's a stuff will not endure. (Zhi, 1998: 48-49)

Besides English poetry, Chinese Tang dynasty also witnessed the emergence of this motif, which was reflected in јиеји (a poem of four lines, each containing five or seven characters, with a strict tonal pattern and rhyme scheme):

劝君莫惜金缕衣, 劝君惜取少年时。

花开堪折直须折, 莫待无花空折枝。(Wang, 1983: 256)

Strangely enough, although many a male poet expressed Carpe Diem motif in their poetry, there is what I term a distinguished "anti-Carpe-Diem" motif in one English poem. In 1747 Lady Mary Wortley Montagu wrote The Lover: A Ballad, which is a brilliant counter to the Carpe Diem poems written by male poets; in it, the speaker explains to her importunate lover why she finds him utterly resistible. Below is the last stanza of The Lover: A Ballad:

I never will share with the wanton coquette,

Or be caught by a vain affectation of wit.

The toasters and songsters may try all their art,

But never shall enter the pass of my heart.

I loath the lewd rake, the dress'd fopling despise:

Before such pursuers the nice virgin flies:

And as Ovid has sweetly in parable told,

We harden like trees, and like rivers grow cold. ${ }^{5}$

\section{CARPE DIEM IN FICTION}

With the great influence of Carpe Diem upon poetry, fictions are also more or less assimilated by this time-honored theme. In the $20^{\text {th }}$ century literature, there emerges the novella Seize the Day (1956) by Saul Bellow. Considered by many critics to be Bellow's finest work of fiction, the novella was immediately singled out from among its companion pieces as a major work. The powerful impact of Seize the Day comes from its tightly constructed plot; from Bellow's ability to control effectively in a concentrated form such enormous themes as victimization, alienation, and human connection; and from his creation of Tommy Wilhelm, one of his most moving protagonists. Bellow's work before Seize the Day had attracted the attention of readers and critics, but he was particularly praised for his achievement in this

\footnotetext{
${ }^{5}$ See also http://www.poetry-archive.com/m/the_lover_a_ballad.html
} 
fourth novel, which demonstrates his attainment of full artistic maturity. ${ }^{6}$

At the heart of the action in Seize the Day, Tommy Wilhelm's relationship with his father revolves around Tommy's neediness and his father's disapproval of him. Tommy's problems with his father feed yet another theme of the novel and of Bellow's fiction in general: alienation from oneself and from humanity. Tommy feels cut off not only from his father and from the rest of his family - his sister, his dead mother, his estranged wife and their two sons - but he also feels alienated from himself and from everyone he meets. Bellow's ability to treat weighty themes in Seize the Day, while making Tommy Wilhelm a pitiable yet sympathetic character, explains the success of this novella: it is capable of seizing both the reader's mind and heart. ${ }^{7}$

This novella borrowed its title from Horace, an ancient Roman poet, who once wrote in his poem Carpe Diem, quam minimum credula postero! (Seize the day, put no trust in tomorrow). But in this novella, this title has been endowed with many interpretations. Firstly, seize the day can be interpreted as Tamkin's advice to Wilhelm. Tamkin claimed himself to be spiritual trauma psychologist. He exhorted Wilhelm to get rid of past sorrow and not to be preoccupied with future anxieties and to make the most of present time. Secondly, seize the day may as well be regarded as writer's exhortation towards those Wilhelm-like persons, urging them to seize the opportunity and be aware of their own situations and recognize mistakes. They should turn over a new leaf in leading a brand-new life. We can also literally interpret the title as seize this very day. This very day is critically important to both Wilhelm and Tamkin, for it decides the make-or-break of their speculative business. We can also approach this title as an irony employed by the writer. Wilhelm and Tamkin spared no efforts to speculate in commodity business, only to end up in sheer bankruptcy. This ending is undoubtedly an utmost irony towards this money-centered society.

All in all, Seize the day is rich in connotations. Anyway, Carpe Diem in this novella has evolved into many variations. It is not about seeking physical pleasures, but about seizing the right moment to do the right deed.

\section{CARPE DIEM IN FILM}

Apart from poems and fictions, Carpe Diem can as well be employed in films. Here, I would like to comment on one of my favorite films, Dead Poets Society, of which Carpe Diem is the heart. Dead Poets Society is one of America's most-loved films. Its message is a reflection of some of America's highest cultural values - that of individualism, creativity, and risk-taking. The 1989 film depicts a struggle between the philosophies of realism and romanticism, conservatism and liberalism. Realism is concerned with reality and facts while rejecting emotions and dreams. Romanticism focuses on the individual, imagination, emotions, spontaneity, freedom and experimentation. Conservatism tends to tradition and the status quo, while liberalism concentrates on change and innovation.

The film depicts Mr. John Keating, a new teacher with personal charisma and unique teaching methods in a traditional noble school. In the students' eyes, he was regarded as spiritual savor. In the film, Mr. Keating taught classic literature. In the very first class, he encouraged his students to rip off the entire introduction of the textbook so as to let them feel their passion, their tolerance and the power of literature. In his words, "We don't read and write poetry because it's cute. We read and write poetry because we are members of the human race. And the human race is filled with passion. And medicine, law, business, engineering - these are noble pursuits and necessary to sustain life. But poetry, beauty, romance, love - these are what we stay alive for." ${ }^{, 8}$ These lines reveal the importance of literature and the meaning of human existence. Mr. Keating's classes are anything but traditional. He challenges his students to reject conformity, to look at life in new ways, and to live life to the fullest by exclaiming, "Carpe Diem, lads! Seize the day. Make your lives extraordinary!" The Latin phrase, "Carpe Diem," meaning "seize the day," is at the heart of Dead Poets Society. Because of this movie, the phrase "Carpe Diem" has become a part of American culture and language, inspiring T-shirts and challenging generations of students to make the most of every day.

In the film there are a couple of famous poetic quotes, all of which manifest the motif of Carpe Diem, individuality, and creativity, such as "Gather ye rosebuds while ye may" (as mentioned in the prior section), and the last stanza from The Road Not Taken by Robert Frost:

Two roads diverged in a wood, and I-

I took the one less traveled by,

And that has made all the differences. (Tao, 2001: 128)

It merits pointing out, however, that the motif in this case in point has changed from pleasure-seeking to time-cherishing, or opportunity-grabbing (as demonstrated in The Road Not Taken). Mr. Keating asked his students to grab every opportunity and to make the most of every day. This variation of Carpe Diem bears educational significance even to the current day. From this movie, the western Carpe Diem cannot be identified with Chinese “及时行乐”. While Chinese 及时行乐 reveals indulgence, desperation and hedonism, the western Carpe Diem renders a positive mindset in negativity. There are active pursuit, romantic dreams, yearning for love, and treasuring for life.

\footnotetext{
${ }^{6}$ See also http://www.encyclopedia.com

7 Ibid.

${ }^{8}$ In Dead Poets Society, this is what Mr. Keating says to his students in class, distinguishing literature from other subjects and revealing the significance of literature.
} 


\section{CONTEMPlation OF CARPE Diem}

William Wordsworth once said, "All good poetry is the spontaneous overflow of powerful feelings: it takes its origin from emotion recollected in tranquility." (Lennard, 2003: 326). A glimpse at $16^{\text {th }}$ and $17^{\text {th }}$ century English poetry gives us a deep impression of Carpe Diem these poems instill. They represent the powerful feelings of poets or ordinary people at that time.

Over the past decades, however, critic academia has rendered inadequate studies in this literary phenomenon. They have either turned a blind eye to it or simply regarded it as negative or even decadent trend of thoughts. This paper is of the opinion that Carpe Diem has an intrinsic relationship with political and religious ambience of that time.

The essence of Carpe Diem can be said to be a spiritual crisis, the existence of which has profound social roots. It is known to all that the $16^{\text {th }}$ to $17^{\text {th }}$ century witnessed great social turbulence and transformation in English history. The seventeenth century, it should be remembered, was not only a period of intense religious and philosophical struggle, but a period of revolutionary scientific and philosophical thought. Since the religious reformation launched by Henry VIII, the constant struggles between establishmentarianism and Puritanism have undermined people's religious belief. The soaring development of science and technology make people realize the greatness of their own but also the insignificance and nihility of human life. It is a time typical of contradictions and resistance. The harmonious state of renaissance was busted. After long period of religious oppression and spiritual crisis, people begin to lay emphasis on the present time, feeling that "Life is a tale told by an idiot, full of sound and fury, signifying nothing." Given this kind of intellectual milieu, readers may easily see the reason why poets during these periods reflected Carpe Diem motif in their works.

In the $19^{\text {th }}$ and $20^{\text {th }}$ century, this very motif has undergone subtle changes. It is more than the so-called pleasure seeking. It emphasizes more upon the ephemeral time and reminds us of our mortality and of time fleeting away. People should make the most of the opportunities.

\section{CONCLUSION}

In the $19^{\text {th }}$ and $20^{\text {th }}$ century, Carpe Diem has gradually evolved into the philosophy of cherishing time with pleasure-seeking no more found in the literary works.

Carpe Diem works, especially poetry in English literature, are loaded with realistic significance and criticism, reflecting the social and historical status quo of certain time. Despite the fact that their works are overflowing with hedonist tendency, such as Let's Die after We've Got Our Highs ${ }^{I 0}$, we are not supposed to fuss about, just blindly criticizing and judging from the perspective of Chinese traditional values. Albeit it has a negative side of view, Carpe Diem may as well be accepted as a positive philosophy of life under given social circumstances. Even under the present situation, it still renders instructional significance to us.

\section{REFERENCES}

[1] Abrams, M. H. (1979). The Norton anthology of English literature. (4 ${ }^{\text {th }}$ ed.). New York and London: W. W. Norton \& Company.

[2] Abrams, M. H. (2005). A glossary of literary terms. ( $8^{\text {th }}$ ed.). USA: Thomson Wadsworth.

[3] Baldick, Chris. (2000). Oxford concise dictionary of literary terms. Shanghai: Shanghai Foreign Language Education Press.

[4] Bian Zhilin. (1996). A Chinese selection of English poetry. Beijing: The Commercial Press.

[5] Bush, Douglas. (1962). English literature in the early seventeenth century 1600-1660. (2 $2^{\text {nd }}$ ed.). New York: Oxford University Press.

[6] Eliot, T. S. (1960). Selected essays. New York: Harcourt, Brace, and World, Inc.

[7] Guerin, Wilfred L., et al. (2004). A handbook of critical approaches to literature. (4 ${ }^{\text {th }}$ ed.). Beijing: Foreign Language Teaching and Research Press.

[8] Hamilton, A. C. (1980). Spenser: The Faerie Queene. London and New York: Longman.

[9] Han, John J. (2003). Love, Time, and Eternity: Teaching Andrew Marvell's To His Coy Mistress. http://mobap.edu/academics/fl/journal/2.1/han.asp.

[10] Lennard, John. (2003). The poetry handbook. (second edition). United States: Oxford University Press.

[11] Lu Gusun. (1993). The English-Chinese dictionary. Shanghai: Shanghai Translation Publishing House.

[12] Luo Yimin. (2004). Time's scythe: A thematic study of Shakespeare's sonnets. Chengdu: Sichuan Cishu Publishing House.

[13] Qian Qing. (1994). Highlights of American literature. (Volume 1 \& 2). Beijing: The Commercial Press.

[14] Quennell, Peter. (1973). A history of English literature. Springfield, MA: G\&C Merriam.

[15] Saintsbury, George. (1966). A short history of English literature. New York: St. Martin's Press.

[16] Sampson, George. (1970). The concise Cambridge history of English literature. (3 ${ }^{\text {rd }}$ ed.). Cambridge: Cambridge University Press.

[17] Tao Jie. (2001). Selected readings in American literature. Beijing: Higher Education Press.

[18] Wang Shouren. (2001). Selected readings in British literature. Beijing: Higher Education Press.

[19] Wang Zuoliang, Li Funing, Zhou Yuliang, Liu Chengpei. (1983). An anthology of English literature annotated in Chinese. Beijing: The Commercial Press.

[20] Zhi Jinzhong. (1998). Chief Editor: Qiu Ke'an, Annotated Shakespeare Vol. 4 Twelfth Night. Beijing: The Commercial Press.

\footnotetext{
${ }^{9}$ Quoted from Shakespeare's Hamlet

10 The title of a book written by Wang Shuo, also entitled Die Just after Enjoying Oneself to the Full
} 


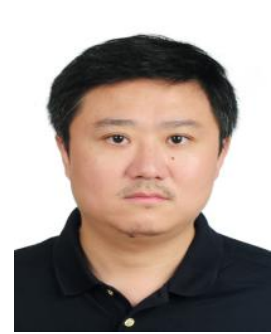

Yi Wang was born in Chongqing, China in 1982. He is currently a $\mathrm{PhD}$ candidate in linguistics from Southwest University, China.

$\mathrm{He}$ is currently a lecturer in the School of Foreign Languages, Chongqing University of Posts and Telecommunications, Chongqing, China. His research interests include cognitive linguistics, construction grammar, the interface between syntax and semantics. 